\title{
THIN LAYER DRYING MODELING OF APPLES AND APRICOTS IN A SOLAR- ASSISTED DRYING SYSTEM
}

\author{
A. Stegou - Sagia ${ }^{1^{\star}}$, D.V. Fragkou ${ }^{1}$
}

\begin{abstract}
This work presents the drying process of apricots and apples which have been considered for drying in a solarassisted forced convection tray dryer. The logarithmic model has been used to describe the drying behavior of apples and apricots at different air temperatures $\left(50{ }^{\circ} \mathrm{C}\right.$ to $\left.80^{\circ} \mathrm{C}\right)$ and at different air velocities $(0.5 \mathrm{~m} / \mathrm{s}$ to $2 \mathrm{~m} / \mathrm{s})$ based on experimental data from several studies.

The slice thickness of apples has been assumed at $10 \mathrm{~mm}$ with initial moisture content $87 \% \mathrm{~d}$. b; the main diameter of apricots was $40 \mathrm{~mm}$ with initial moisture content $80 \% \mathrm{~d}$. b. The changes in moisture content with drying time during the drying period have been presented indicating the absence of the constant rate period.

In addition, drying air flow rates and temperatures had an important effect on the drying time and on the moisture removal from apricots and apples. Finally, the effective moisture diffusivity values have been estimated from Fick's diffusion model pointing out that it has been increased with the increase of the drying air temperature.
\end{abstract}

\section{Keywords: Tray Dryer, Solar Assisted, Apricots, Apples, Logarithmic Model}

\section{INTRODUCTION}

Drying is one of the most popular methods of food preservation which allows dried foods to be stored for long periods without further deterioration in their quality. The drying of food implies the removal of water from the product to an acceptable level for safe storage [1]. Drying of agricultural products under direct sunlight is the traditional way of preservation in the Mediterranean countries. This method is practiced until today for certain products because of the advantages of simplicity and economy [2].

However, open sun drying has some drawbacks such as longer drying time, fungal growth, encroachment of insects, birds and rodents, wind, rain, storm, dirt, dust and environmental pollution [2]. The major advantage in the energy requirements for this open sun drying process is that the solar and wind energy is available freely in nature. Drying in a solar dryer constitutes a safer and efficient alternative process due to better quality products. Solar drying has become a popular method to replace thermal dryers which use high cost fossil fuels [3].

A solar dryer is a device that uses solar energy to dry substances, especially food and it is closed to keep the food safe from damage [4]. Basically, there are four types of solar dryers.

Direct solar dryers expose the substance to be dehydrated in direct sunlight and may have enclosures or glass covers in order to increase efficiency. They have a black absorbing surface which collects the light and converts it to heat; the substance to be dried is placed directly on this surface [5].

In indirect solar dryers solar energy is collected in a separate solar collector (air heater). This heated air passes over the substance and then through the chimney [5].

In mixed-mode dryers, the combined action of the incident solar radiation on the material to be dried and the air preheated in solar collector provides the heat required for the drying operation [6].

In hybrid solar dryers, although the sun is used to dry products, other technologies are also used to cause air movement in the dryers. For example, fans powered by solar PV can be used in these types of dryers [6].

Solar dryers have been used and related experimental studies have been reported concerning the drying of agricultural products such as beans [3], grapes [3, 6], potatoes [7], onions [8, 9], grains [10], figs [11], apples [12], apricots [13, 14, 15], mangoes [16, 17], bananas [17], rough rice [18, 19], pumpkins [9], green peppers [9] and pistachios [20].

This paper was recommended for publication in revised form by Regional Editor Assunta Andreozzi

${ }^{1}$ National Technical University of Athens, School of Mechanical Engineering, Laboratory of Thermal Processes, 9

IroonPolytechniou Street, Zografou 15780 Athens, Greece

${ }^{*}$ E-mail address:asagia@central.ntua.gr

Manuscript Received 16 June 2016, Accepted 28 November 2016 
A number of thin layer equations are also available in the literature for explaining drying behavior of agricultural products. Specifically, the logarithmic model has been used by some investigators to describe drying kinetics for mushrooms [21], apples [22], apricots [23, 24], grapes [25, 26], figs [27], bananas [28], tomatoes [29, 30], pistachios [31] and bell peppers [32].

The main objective of this article is to determine the drying behavior of apricots and apples in an indirect type forced convectional solar dryer relying on experimental results from several articles by using the logarithmic model $\mathrm{MR}=\mathrm{a} \cdot \exp \cdot(-\mathrm{k} \cdot \mathrm{t})+\mathrm{c}$. In addition, the effective moisture diffusivity in the convective drying process of apricots and apples has been calculated. It has been proved that our results are similar to these of other researchers. A comparison has been made between the changes of moisture content and the effective moisture diffusivities of apples and apricots.

\section{MATERIALS AND METHODS Materials and Solar Dryer}

Many investigators have carried out drying experiments using solar dryers and some of them have published their results for apricots and apples drying. Solar dryers have been proposed due to agricultural products drying.

We have chosen the forced convectional solar dryer used by Mohanraj and Chandrasekar in experiments which were carried out for copra [33] and chilli [34] drying. Based on the literature, the dimensions of this dryer are convenient for drying of food, especially for products such as apricots and apples, which we are dealing with in this article. The forced convectional solar dryer consists of an air heater, a drying chamber and a blower/fan to duct the heated air to the drying chamber.

Drying characteristics have been chosen from experimental results given [24] for apricots and [35] for apples with different values of air velocities and temperatures.

The slice thickness of apples has been assumed at $10 \mathrm{~mm}$ with initial moisture content $87 \%$ d. b. Apples had been dried by using drying air temperatures from $50{ }^{\circ} \mathrm{C}$ to $80^{\circ} \mathrm{C}$ at air velocity $1 \mathrm{~m} / \mathrm{s}$. The main diameter of apricots was $40 \mathrm{~mm}$ with initial moisture content $80 \% \mathrm{~d}$. b. Apricots had been dried using air temperatures from $50{ }^{\circ} \mathrm{C}$ to $70{ }^{\circ} \mathrm{C}$ at air velocities 0.5 to $2 \mathrm{~m} / \mathrm{s}$. Other researchers have also selected these drying data as sufficiently suitable for drying apricots and apples [22, 23, 24].

\section{Mathematical Modeling of Drying Data}

Several thin layer drying models have been proposed by researchers describing the moisture transfer in various agricultural products as shown in Table 1 [1]. Liquid or vapor diffusion is assumed to be the primary mechanism of moisture transport in drying of fruit and vegetables and it is described by the Fick's second law [36]:

$$
\frac{\partial M}{\partial t}=D_{e f f} \nabla^{2} M
$$

where $D_{\text {eff }}\left(\mathrm{m}^{2} / \mathrm{s}\right) \quad$ is the effective moisture diffusivity and $M$ the moisture content at any time $\%$ d.b.

The first term of the solution of Equation 1, after making some simplifications i.e constant diffusivity, no shrinkage, suitable boundary conditions for spherical bodies produces Eq. 2 .

$$
M R=\frac{8}{\pi^{2}} \exp \left(-\frac{\pi^{2} D_{e f f} t}{4 L^{2}}\right)
$$

where $M R$ stands for $\frac{M-M_{e q}}{M_{0}-M_{e q}}$ the dimensionless form of moisture content, $L$ the thickness of the slab $(m)$ and $t$ the drying time in $(s)$. We have presented in [21] the complete equation type for MR calculation.

Equation 2 can also be written in a more simplified form as:

$$
\begin{aligned}
& M R=a \cdot \exp (-k \cdot t) \\
& M R=a \cdot \exp (-k \cdot t)+c
\end{aligned}
$$


Equation 3 is known to be the exponential or Lewis model and Equation 4 the logarithmic model. The Lewis model is considered to be the simplest model to describe the moisture movement in dried products [37]. Based on other works related to mathematical modeling of drying of apricots and apples, the logarithmic model appears to be a suitable model attributing accurately their drying characteristics [15, 22, 23, 24, 35].

Table 1. Mathematical models for the drying curves

\begin{tabular}{|lrr|}
\hline Model equation & & Lewis \\
\hline$M R=\exp (-k \cdot t)$ & Henderson \&Pabis & {$[37]$} \\
\hline$M R=a \cdot \exp (-k \cdot t)$ & Logarithmic & {$[36]$} \\
\hline$M R=a \cdot \exp (-k \cdot t)+c$ & Two-term exponential & {$[39]$} \\
\hline$M R=a \cdot \exp \left(-k_{0} \cdot t\right)+b \cdot \exp \left(-k_{1} \cdot t\right)$ & Page & {$[19]$} \\
\hline$M R=\exp \left(-k \cdot t^{n}\right)$ & Modified Page & {$[40]$} \\
\hline$M R=\alpha \cdot\left[\exp \left(-k \cdot t^{n}\right)\right]$ & Wang and Singh & {$[41]$} \\
\hline$M R=1+\alpha \cdot t+b \cdot t^{2}$ & Midilli et al. & {$[42,43]$} \\
\hline$M R=a \cdot \exp \left(-k \cdot t^{n}\right)+b \cdot t$ & Diffusion approach & {$[44]$} \\
\hline$M R=a \cdot \exp (-k \cdot t)+(1-a) \cdot \exp (-k \cdot b \cdot t)$ & Modified Henderson \& Pabis & {$[46]$} \\
\hline$M R=a \cdot \exp (-k \cdot t)+b \cdot \exp (-g \cdot t)+c \cdot \exp (-h \cdot t)$ & Verma et al. & \\
\hline$M R=a \cdot \exp (-k \cdot t)+(1-a) \cdot \exp (-g \cdot t)$ & & \\
\hline
\end{tabular}

\section{RESULTS AND DISCUSSION}

\section{Influence of the air parameters on the drying curves and on the effective moisture diffusivity $D_{\text {eff }}$ of apricots}

We considered that the apricots were dried at 50,60 and $70{ }^{\circ} \mathrm{C}$ and at $0.5,1,1.5$ and $2 \mathrm{~m} / \mathrm{s}$ in a solar-assisted forced convectional tray dryer. Their main diameter was $40 \mathrm{~mm}$ and their moisture content was decreased from 80 $\%$ d.b to $10 \%$. The drying curves of apricots have been built by using the logarithmic model MR $=a \cdot \exp \cdot(-k \cdot t)+c$ and are presented in Figure 1.

It is apparent that moisture ratio decreases continuously with drying time. Analysis of the drying curve has shown no constant rate period. The drying has taken place in the falling rate period. The moisture ratio MR versus drying time is shown in Figure 1 for the selected values of air velocity and at constant air temperature.

Obviously, increasing drying air velocity, a decrease in drying time is observed. These results are in agreement with other results reported for drying of apricots such as [24].

Table 2 shows the drying time (min) under different air temperatures and air velocities.

Table 2.Time (min) of apricot drying from $80 \%$ to $10 \%$ moisture content.

\begin{tabular}{|c|c|c|}
\hline $\begin{array}{c}\text { Drying air temperature, } \\
\mathbf{T}\left({ }^{\circ} \mathbf{C}\right)\end{array}$ & $\begin{array}{c}\text { Drying air velocity, } \\
\mathbf{V}(\mathbf{m} / \mathbf{s})\end{array}$ & $\begin{array}{c}\text { Drying time } \\
(\mathbf{m i n})\end{array}$ \\
\hline 50 & 0.5 & 576 \\
\hline 60 & 0.5 & 534 \\
\hline 70 & 0.5 & 498 \\
\hline 50 & 1 & 480 \\
\hline 60 & 1 & 450 \\
\hline 70 & 1 & 420 \\
\hline 50 & 1.5 & 402 \\
\hline 60 & 1.5 & 384 \\
\hline 70 & 1.5 & 360 \\
\hline 50 & 2 & 348 \\
\hline 60 & 2 & 330 \\
\hline 70 & 2 & 318 \\
\hline
\end{tabular}



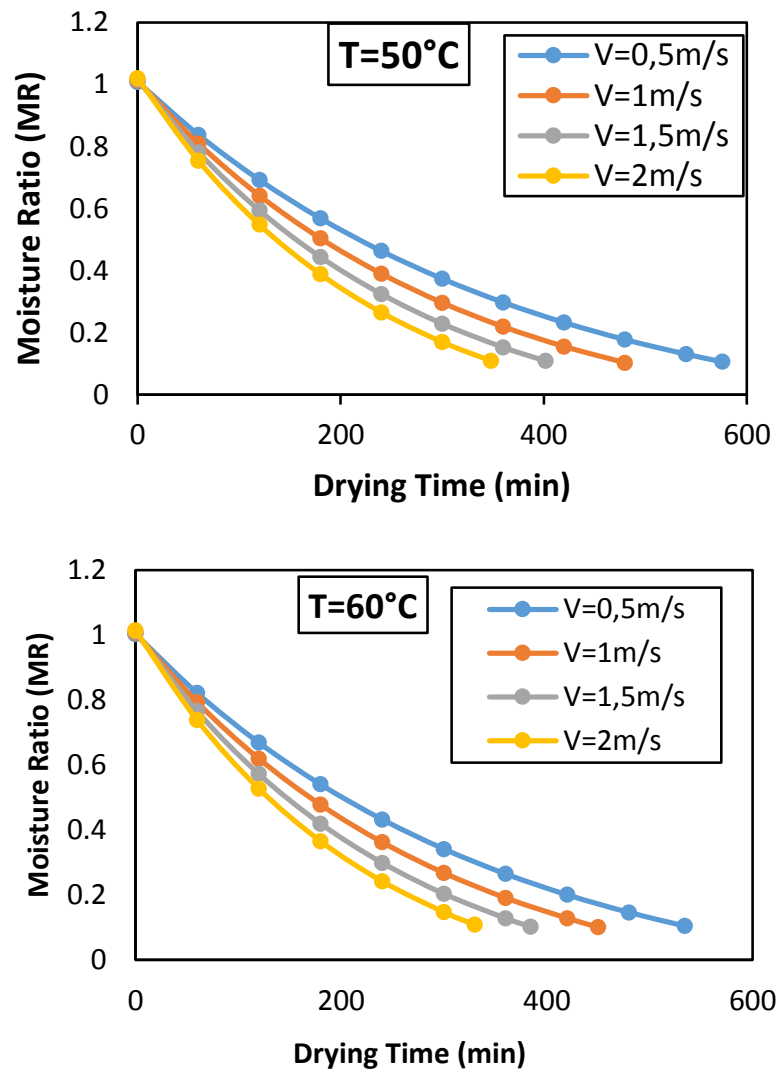

(a)

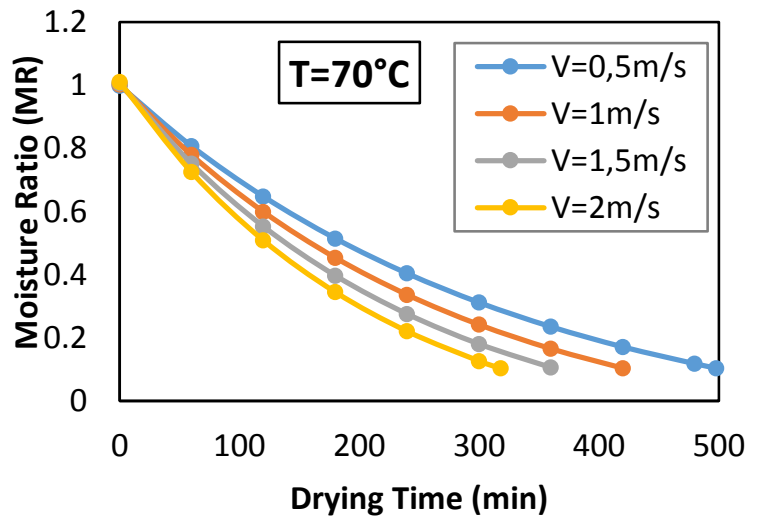

(b)

(c)

Figure 1. Air velocity effect on the drying curves for air temperature $50{ }^{\circ} \mathrm{C}(\mathrm{a}), 60^{\circ} \mathrm{C}$ (b) and $70{ }^{\circ} \mathrm{C}(\mathrm{c})$

Figure 2 presents the drying curves for different air temperatures 50,60 and $70{ }^{\circ} \mathrm{C}$ at air velocities $0.5,1.5$ and $2 \mathrm{~m} / \mathrm{s}$, respectively. It is evident that drying air temperature has a significant effect on the drying time, as higher air drying temperatures shorten the drying time.

The drying time is decreased when air velocity increases in equal intervals of $0.5 \mathrm{~m} / \mathrm{s}$ between 0.5 to $2 \mathrm{~m} / \mathrm{s}$ as it is depicted in Table 3.

Furthermore, there is a decrease in drying time when air temperature is increased from 50 to $70{ }^{\circ} \mathrm{C}$ with a $10^{\circ} \mathrm{C}$ step as it is shown in Table 4.

Therefore, the zone for air velocities between 0.5 to $1 \mathrm{~m} / \mathrm{s}$ and temperatures between 50 to $60{ }^{\circ} \mathrm{C}$ is the best option for drying apricots, due to the greatest effect on the drying time decrease, namely, $16.68 \%$ and $7.32 \%$ correspondingly.

Table 5 presents the coefficients for logarithmic model during the drying of apricots.

Figure 5 exemplifies the Ln (MR) (Moisture Ratio) as a function of time (h) at air temperature $50^{\circ} \mathrm{C}$ with velocities 1 and $2 \mathrm{~m} / \mathrm{s}$. The plotted curves show that the increase in temperature increases the slope of straight line, or in other words the effective moisture diffusivity is increased. 

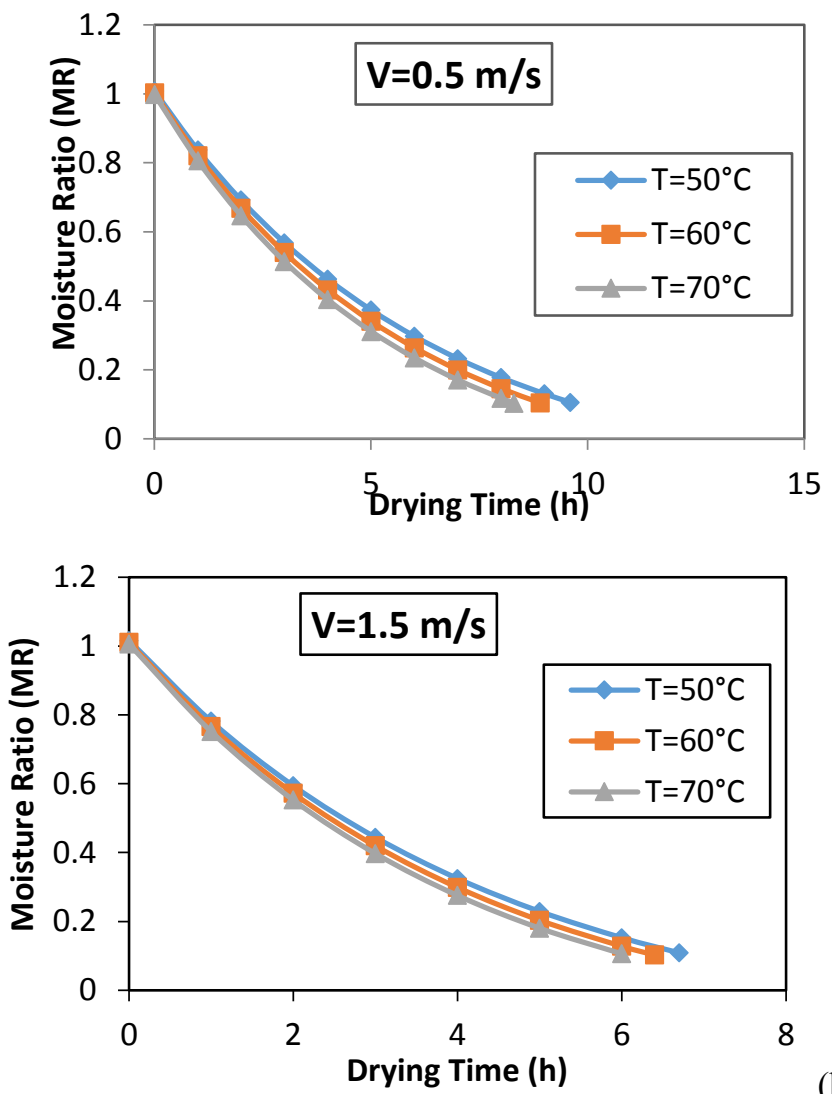

(a)

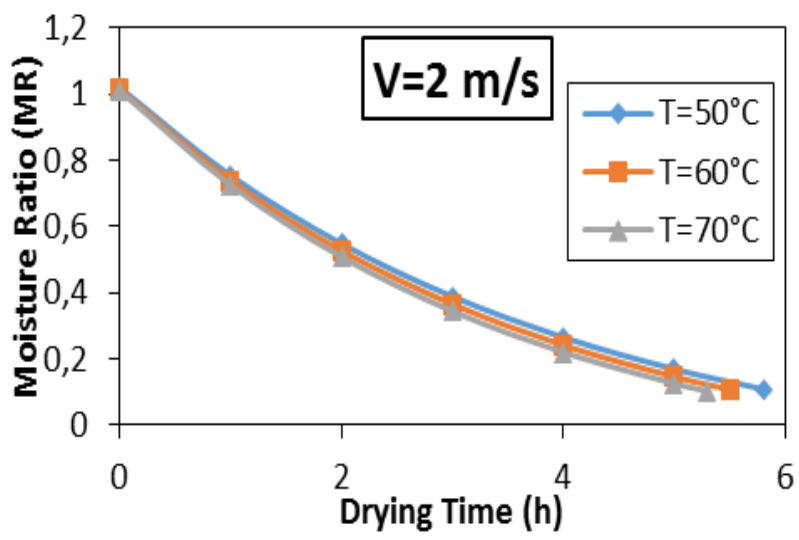

(b)

Figure 2. Drying curves for different air temperatures at velocities $0.5 \mathrm{~m} / \mathrm{s} \mathrm{m} / \mathrm{s}(\mathrm{a}), 1.5$ (b) and $2 \mathrm{~m} / \mathrm{s}$ (c).

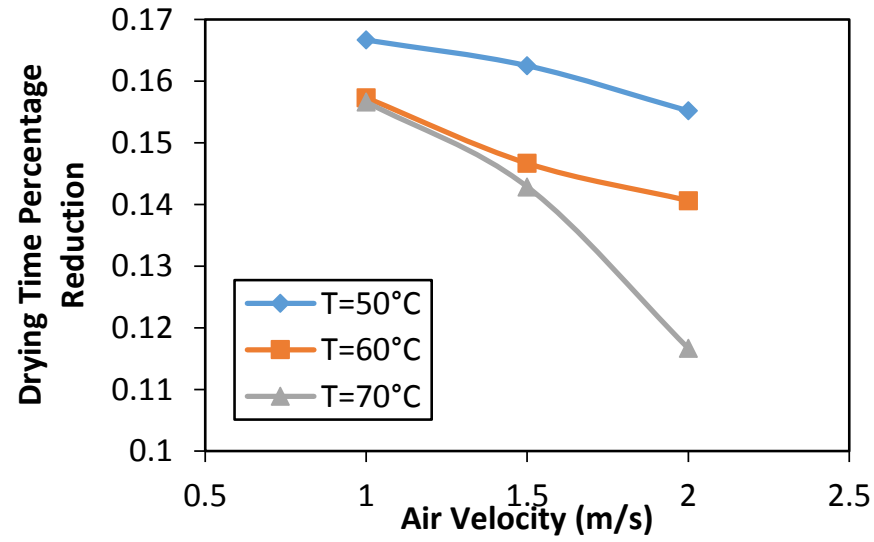

Figure 3. Drying time percentage reduction versus air velocity at different values of temperature 


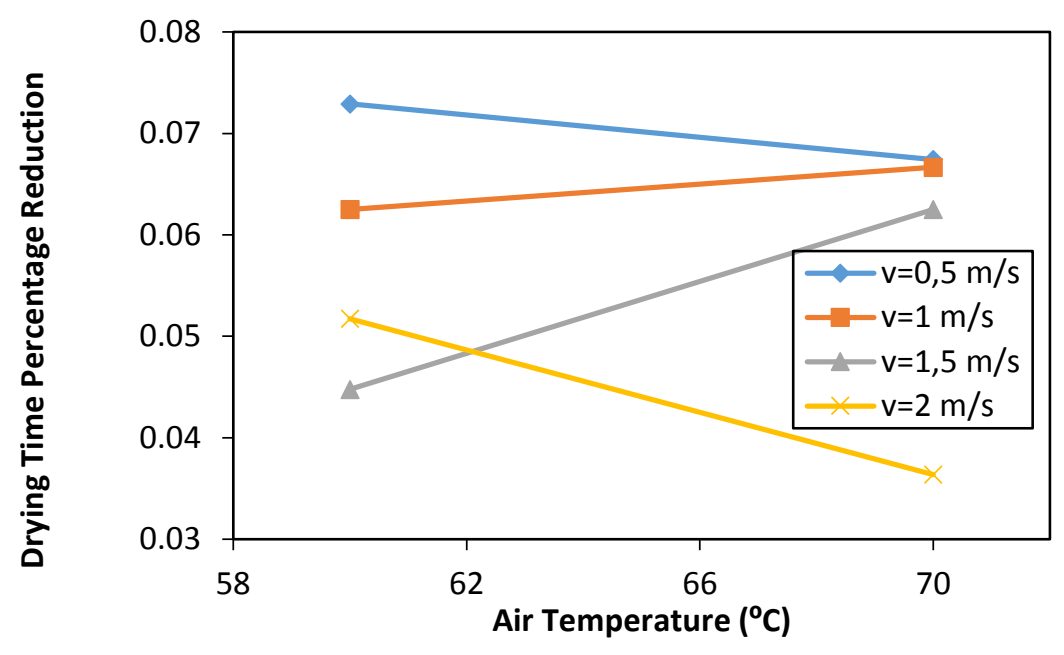

Figure 4. Drying time percentage reduction versus air temperature at different values of velocity

Table 3.Drying time percentage reduction for certain temperature in equal intervals of $0.5 \mathrm{~m} / \mathrm{s}$

\begin{tabular}{|c|c|c|}
\hline $\mathbf{T ~}\left({ }^{\circ} \mathbf{C}\right)$ & $\mathbf{V ~}(\mathbf{m} / \mathbf{s})$ & Percentage Reduction $(\%)$ \\
\hline 50 & $0.5-1$ & 16.68 \\
\hline 50 & $1-1.5$ & 16.25 \\
\hline 50 & $1.5-2$ & 13.43 \\
\hline 60 & $0.5-1$ & 15.73 \\
\hline 60 & $1-1.5$ & 14.67 \\
\hline 60 & $1.5-2$ & 14.06 \\
\hline 70 & $0.5-1$ & 15.66 \\
\hline 70 & $1-1.5$ & 14.29 \\
\hline 70 & $1.5-2$ & 11.67 \\
\hline
\end{tabular}

.Table 4. Drying time percentage reduction for certain velocity in equal steps of $10^{\circ} \mathrm{C}$.

\begin{tabular}{|c|c|c|}
\hline $\mathbf{V}(\mathbf{m} / \mathbf{s})$ & $\mathbf{T}\left({ }^{\circ} \mathbf{C}\right)$ & Percentage Reduction $(\%)$ \\
\hline 0.5 & $50-60$ & 7.32 \\
\hline 1 & $50-60$ & 6.74 \\
\hline 1.5 & $50-60$ & 6.25 \\
\hline 2 & $50-60$ & 6.67 \\
\hline 0.5 & $60-70$ & 4.48 \\
\hline 1 & $60-70$ & 6.32 \\
\hline 1.5 & $60-70$ & 5.17 \\
\hline 2 & $60-70$ & 3.63 \\
\hline
\end{tabular}

Figure 6 shows the effective moisture diffusivity $D_{\text {eff }}$ variation with air temperature at different levels of air velocity.

Figure 7 presents the effective moisture diffusivity $D_{\text {eff }}$ versus air velocity at different levels of air temperature.

The values of the effective moisture diffusivity $D_{\text {eff }}$ were ranged from $8.29 \times 10^{-10} \mathrm{~m}^{2} / \mathrm{s}$ to $18.9 \times 10^{-10} \mathrm{~m}^{2} / \mathrm{s}$. The maximum value of moisture diffusivity was $18.9 \times 10^{-10} \mathrm{~m}^{2} / \mathrm{s}$ when air velocity was $1 \mathrm{~m} / \mathrm{s}$ and air temperature was $50^{\circ} \mathrm{C}$. The minimum value of moisture diffusivity has been calculated equal to $8.29 \times 10^{-10} \mathrm{~m}^{2} / \mathrm{s}$ at $2 \mathrm{~m} / \mathrm{s}$ air velocity and $70^{\circ} \mathrm{C}$ air temperature. As we have already seen the maximum value of diffusivity has been found for the minimum air velocity value. Mirzaee et al. [23] reported that the minimum value of moisture diffusivity for 
apricots was varied between $1.78 \times 10^{-10} \mathrm{~m}^{2} / \mathrm{s}$ to $5.11 \times 10^{-10} \mathrm{~m}^{2} / \mathrm{s}$. Togrul and Pehlivan [24] gave almost same values, $6.51 \times 10^{-9} \mathrm{~m}^{2} / \mathrm{s}$ to $8.32 \times 10^{-9} \mathrm{~m}^{2} / \mathrm{s}$. Our results are comparable.

Table 5. Regression analysis coefficients for logarithmic model MR $=\mathrm{a} \exp (-\mathrm{k} \cdot \mathrm{t})+\mathrm{c}$.

\begin{tabular}{|l|l|ll|}
\hline $\mathbf{T}\left({ }^{\circ} \mathbf{C}\right)$ & $\mathbf{V}(\mathbf{m} / \mathbf{s})$ & Coefficients $(\mathbf{a}, \mathbf{k}, \mathbf{c})$ & \\
\hline 50 & 0.5 & $\mathrm{a}=1.1453, \quad \mathrm{k}=0.0027, \quad \mathrm{c}=0.1365$ \\
\hline 50 & 1 & $\mathrm{a}=1.1558, \quad \mathrm{k}=0.0032, \quad \mathrm{c}=0.1434$ \\
\hline 50 & 1.5 & $\mathrm{a}=1.1665, \quad \mathrm{k}=0.0037, \quad \mathrm{c}=0.1503$ \\
\hline 50 & 2 & $\mathrm{a}=1.1773, \quad \mathrm{k}=0.0043, \quad \mathrm{c}=0.1572$ \\
\hline 60 & 0.5 & $\mathrm{a}=1.1453, \quad \mathrm{k}=0.0029, \quad \mathrm{c}=0.1424$ \\
\hline 60 & 1 & $\mathrm{a}=1.1558, \quad \mathrm{k}=0.0034, \quad \mathrm{c}=0.1493$ \\
\hline 60 & 1.5 & $\mathrm{a}=1.1665, \quad \mathrm{k}=0.0039, \quad \mathrm{c}=0.1562$ \\
\hline 60 & 2 & $\mathrm{a}=1.1773, \quad \mathrm{k}=0.0045, \quad \mathrm{c}=0.1631$ \\
\hline 70 & 0.5 & $\mathrm{a}=1.1453, \quad \mathrm{k}=0.0031, \quad \mathrm{c}=0.1465$ \\
\hline 70 & 1 & $\mathrm{a}=1.1558, \quad \mathrm{k}=0.0036, \quad \mathrm{c}=0.1534$ \\
\hline 70 & 1.5 & $\mathrm{a}=1.1665, \quad \mathrm{k}=0.0041, \quad \mathrm{c}=0.1603$ \\
\hline 70 & 2 & $\mathrm{a}=1.1773, \quad \mathrm{k}=0.0046, \quad \mathrm{c}=0.1672$ \\
\hline
\end{tabular}

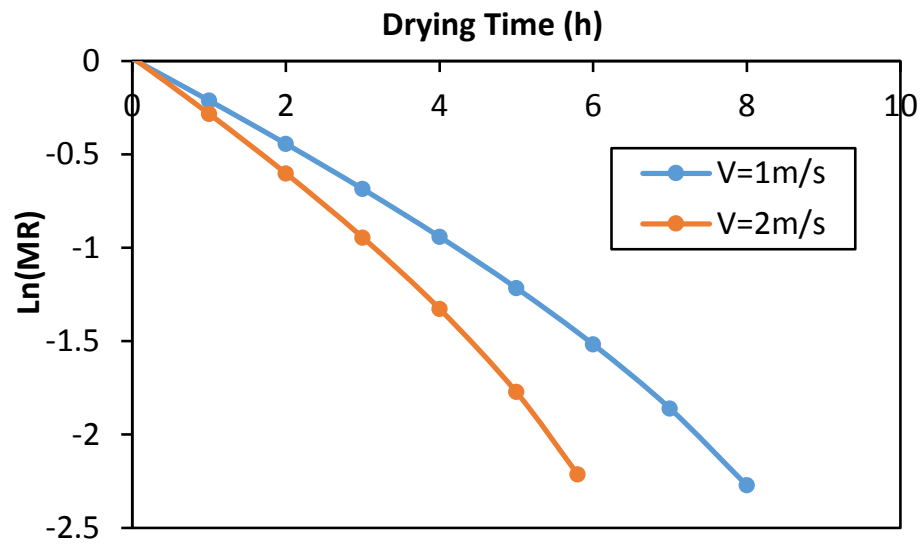

Figure 5. Ln (MR) with drying time (h) at air velocities 1 and $2 \mathrm{~m} / \mathrm{s}$.

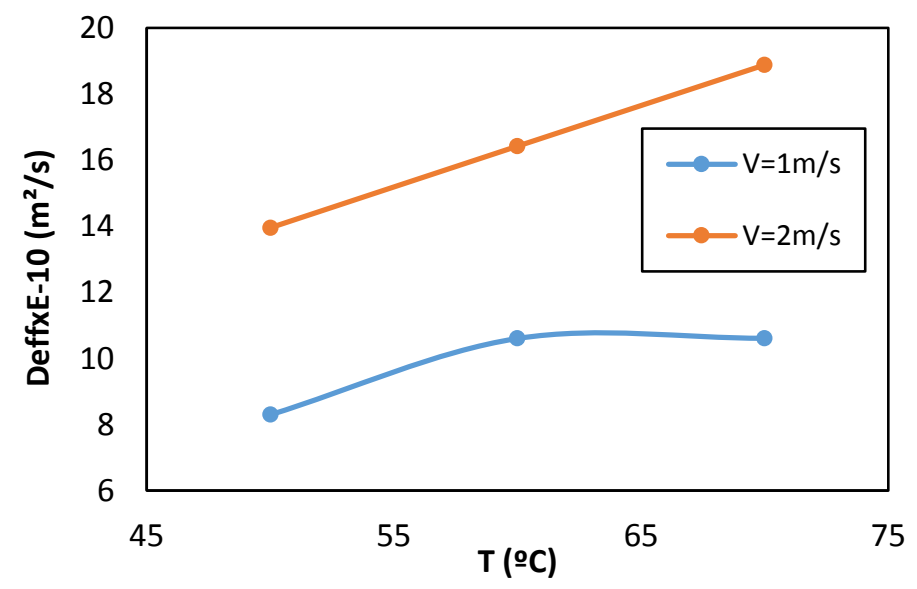

Figure 6. $D_{\text {eff }}$ for various air temperatures and velocities 1 and $2 \mathrm{~m} / \mathrm{s}$. 


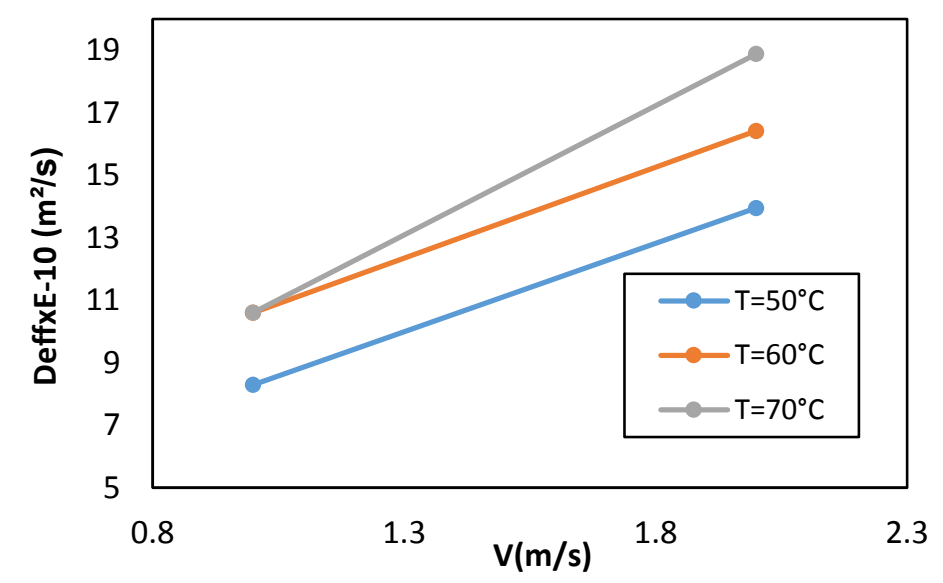

Figure 7. $D_{\text {eff }}$ as a function of air velocity and temperatures 50,60 and $70{ }^{\circ} \mathrm{C}$.

Influence of the air temperature on the drying curves and on the effective moisture diffusivity $D_{\text {eff }}$ of apples

The drying behavior of apples using the logarithmic model $M R=a \cdot \exp (-k \cdot t)+c$ is presented in Figure 8 for constant air velocity $1 \mathrm{~m} / \mathrm{s}$ and selected temperatures $50,60,70$ and $80^{\circ} \mathrm{C}$. The drying process stopped until the water content of apples, $87 \% \mathrm{~d}$. b, reached the level of $10 \%$.

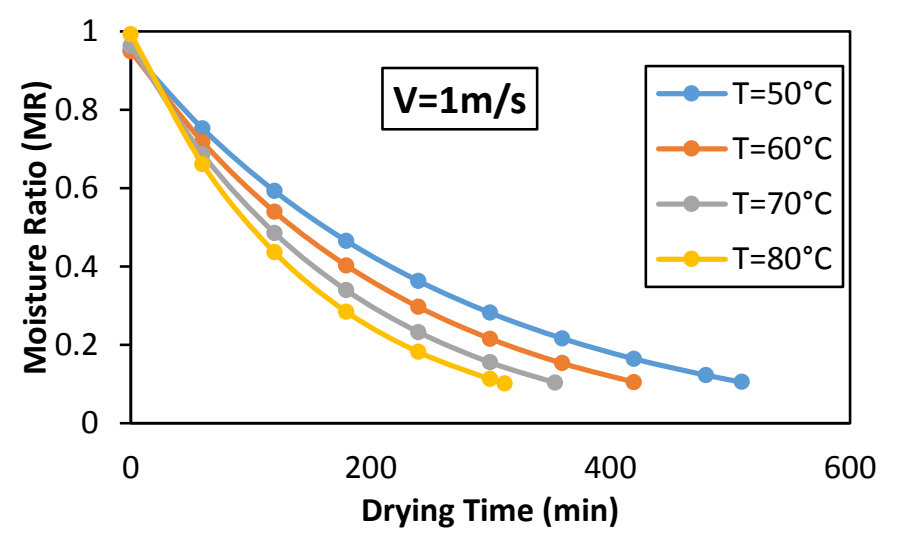

Figure 8. Drying curves for apples dried at different air temperatures and air velocity $1 \mathrm{~m} / \mathrm{s}$.

Table 6.Total drying time (min) under different drying conditions

\begin{tabular}{|c|c|c|}
\hline $\begin{array}{c}\text { Drying air temperature, } \\
\mathbf{T}\left({ }^{\circ} \mathbf{C}\right)\end{array}$ & $\begin{array}{c}\text { Drying air velocity, } \\
\mathbf{V}(\mathbf{m} / \mathbf{s})\end{array}$ & $\begin{array}{c}\text { Drying time } \\
(\mathbf{m i n})\end{array}$ \\
\hline 50 & 1 & 510 \\
\hline 60 & 1 & 420 \\
\hline 70 & 1 & 354 \\
\hline 80 & 1 & 312 \\
\hline
\end{tabular}

Table 7. Effective moisture diffusivity under different drying temperatures

\begin{tabular}{|c|c|c|}
\hline $\boldsymbol{D}_{\text {eff }}\left(\times \mathbf{1 0}^{\mathbf{- 1 0}}\right)$ & $\mathbf{T}\left({ }^{\circ} \mathbf{C}\right)$ & $\mathbf{V ~}(\mathbf{m} / \mathbf{s})$ \\
\hline 5.49 & 50 & 1 \\
\hline 6.62 & 60 & 1 \\
\hline 8 & 70 & 1 \\
\hline 9.54 & 80 & 1 \\
\hline
\end{tabular}




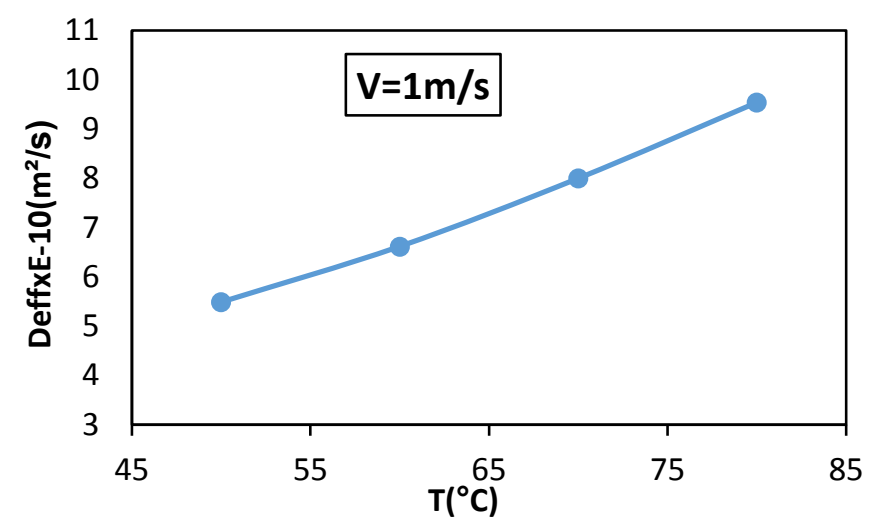

Figure 9. $D_{e f f}$ versus air temperature at air velocity $1 \mathrm{~m} / \mathrm{s}$.

The values of the effective moisture diffusivity ranged from $5.49 \times 10^{-10} \mathrm{~m}^{2} / \mathrm{s}$ to $9.54 \times 10^{-10} \mathrm{~m}^{2} / \mathrm{s}$. We observe that this value is smaller than this which we have mentioned above for apricots.

\section{Comparisons between apricots and apples}

Table 8 presents the drying time of fruits under consideration at air velocity $1 \mathrm{~m} / \mathrm{s}$.

Table 8. Drying time of apples and apricots under the same air velocity $1 \mathrm{~m} / \mathrm{s}$.

\begin{tabular}{|c|c|c|}
\hline $\mathbf{T}\left({ }^{\circ} \mathbf{C}\right)$ & Apricots (min) & Apples (min) \\
\hline 50 & 480 & 510 \\
\hline 60 & 450 & 420 \\
\hline 70 & 420 & 354 \\
\hline
\end{tabular}

We observe that as air temperature becomes higher apples need shorter time to reach the required level of final moisture content than apricots do. However, at $50{ }^{\circ} \mathrm{C}$ the total drying time of apples is inevitably larger than that of the apricots.

Table 9. Effective moisture diffusivity of apples and apricots under the same air velocity $1 \mathrm{~m} / \mathrm{s}$.

\begin{tabular}{|c|c|c|}
\hline $\mathbf{T}\left({ }^{\circ} \mathbf{C}\right)$ & $\begin{array}{c}\text { Apricots } \\
\mathbf{D}_{\text {eff }}\left(\times \mathbf{1 0}^{-\mathbf{1 0}}\right)\end{array}$ & $\begin{array}{c}\text { Apples } \\
\left.\mathbf{D}_{\text {eff }} \times \mathbf{1 0}^{-\mathbf{1 0}}\right)\end{array}$ \\
\hline 50 & 8.29 & 5.49 \\
\hline 60 & 10.6 & 6.62 \\
\hline 70 & 10.7 & 8 \\
\hline
\end{tabular}

Here, one can witness that the apricots moisture diffusivity in comparison to that of apples is higher, at the stated temperatures.

\section{CONCLUSIONS}

The drying process of apricots and apples, with about $40 \mathrm{~mm}$ diameter and $10 \mathrm{~mm}$ thickness, in a forced convection solar dryer has been studied. The drying curves have been built by using the logarithmic model $M R=$ $a \cdot \exp (-k \cdot t)+c$. Our conclusions are summarized below:

- The drying time decreases as the drying air temperature increases. The time fluctuation values are 576 to 318 min for air temperatures 50 to $70{ }^{\circ} \mathrm{C}$ and air velocities 0.5 to $2 \mathrm{~m} / \mathrm{s}$ regarding apricots. For apples the quantities are 510 to $312 \mathrm{~min}$ when temperature varies between 50 to $80^{\circ} \mathrm{C}$ and the air temperature is $1 \mathrm{~m} / \mathrm{s}$.

- The zone between air velocities 0.5 to $1 \mathrm{~m} / \mathrm{s}$ and temperatures 50 to $60{ }^{\circ} \mathrm{C}$ is the best option for apricots drying.

- The average values of effective diffusivities vary between $8.29 \times 10^{-10} \mathrm{~m}^{2} / \mathrm{s}$ to $18.9 \times 10^{-10} \mathrm{~m}^{2} / \mathrm{s}$ at air temperatures 50 to $70^{\circ} \mathrm{C}$ for apricots drying and from $5.49 \times 10^{-10} \mathrm{~m}^{2} / \mathrm{s}$ to $9.54 \times 10^{-10} \mathrm{~m}^{2} / \mathrm{s}$ at air temperatures between 50 and $80^{\circ} \mathrm{C}$ for drying of apples.

- As air temperature increases apples need shorter time to reach the required level of final moisture content than apricots do. 


\section{NOMENCLATURE}

$\begin{array}{ll}M & \text { moisture content at any time \% d.b. } \\ M_{\text {eq }} & \text { equilibrium moisture content \% d.b } \\ M_{0} & \text { initial moisture content \% d.b. } \\ M & \text { moisture ratio, dimensionless } \\ D_{\text {eff }} & \text { effective moisture diffusivity }\left(\mathrm{m}^{2} / \mathrm{s}\right) \\ \mathrm{DR} & \text { drying rate } \\ \mathrm{T} & \text { air temperature }\left({ }^{\circ} \mathrm{C}\right) \\ \mathrm{V} & \text { air velocity }(\mathrm{m} / \mathrm{s}) \\ \mathrm{L} & \text { slab thickness }(\mathrm{m}) \\ \text { d.b } & \text { dry weight basis } \\ \text { w.b } & \text { wet weight basis } \\ \text { a, b, c, n, g, h } & \text { constants of models } \\ \mathrm{k}, \mathrm{k}_{0}, \mathrm{k}_{1} & \text { constants of models } \\ \mathrm{t} & \text { drying time }(\mathrm{s})\end{array}$

\section{REFERENCES}

[1] Stegou-Sagia, A., \& Fragkou, D. (2015). Influence of drying conditions and mathematical models on the drying curves and the moisture diffusivity of mushrooms. Journal of Thermal Engineering, 1(4), 235-244.

[2] Gatea, A. A. (2011). Design and construction of a solar drying system, a cylindrical section and analysis of the performance of the thermal drying system. African Journal of Agricultural Research, 6(2), 343-351.

[3] Pangavhane, D. R., Sawhney, R. L., \& Sarsavadia, P. N. (2002). Design, development and performance testing of a new natural convection solar dryer. Energy, 27(6), 579-590.

[4] Mujumdar, A. S. (2015). Handbook of Industrial Drying Fourth Edition. CRC Press, 1-1288.

[5] Sodha, M. S., \& Chandra, R. (1994). Solar drying systems and their testing procedures: A review. Energy Conversion and Management, 35(3), 219-267.

[6] Jairaj, K. S., Singh, S. P., \& Srikant, K. (2009). A review of solar dryers developed for grape drying. Solar Energy, 83(9), 1698-1712.

[7] Tripathy, P. P., \& Kumar, S. (2008). Determination of temperature dependent drying parameters for potato cylinders and slices during solar drying. Energy Conversion and Management, 49(11), 2941-2948.

[8] Sarsavadia, P. N. (2007). Development of a solar-assisted dryer and evaluation of energy requirement for the drying of onion. Renewable Energy, 32(15), 2529-2547.

[9] Yaldýz, O., \& Ertekýn, C. (2001). Thin layer solar drying of some vegetables. Drying Technology, 19(3-4), 583-597.

[10] Thoruwa, T. F. N., Smith, J. E., Grant, A. D., \& Johnstone, C. M. (1996). Developments in solar drying using forced ventilation and solar regenerated desiccant materials. Renewable Energy, 9(1), 686-689.

[11] Doymaz, I. (2005). Sun drying of figs: An experimental study. Journal of Food Engineering, 71(4), 403-407.

[12] Elicin, A. K., \& Sacilik, K. (2005). An experimental study for solar tunnel drying of apple. Tarim Bilimleri, 11(2), 207-11.

[13] Karabulut, I., Topcu, A., Duran, A., Turan, S., \& Ozturk, B. (2007). Effect of hot air drying and sun drying on color values and $\beta$-carotene content of apricot (Prunus armenica L.). LWT - Food Science and Technology, 40(5), 753-758.

[14] Akpinar, E. K., Sarsilmaz, C., \& Yildiz, C. (2004). Mathematical modelling of a thin layer drying of apricots in a solar energized rotary dryer. International Journal of Energy Research, 28(8), 739-752.

[15] Togrul, I. T., \& Pehlivan, D. (2002). Mathematical modelling of solar drying of apricots in thin layers. Journal of Food Engineering, 55(3), 209-216.

[16] Dissa, A. O., Bathiebo, D. J., Desmorieux, H., Coulibaly, O., \& Koulidiati, J. (2011). Experimental characterisation and modelling of thin layer direct solar drying of Amelie and Brooks mangoes. Energy, 36(5), $2517-2527$.

[17] Gbaha, P., Yobouet Andoh, H., Kouassi Saraka, J., Kaménan Koua, B., \& Touré, S. (2007). Experimental investigation of a solar dryer with natural convective heat flow. Renewable Energy, 32(11), 1817-1829.

[18] Zaman, M. A., \& Bala, B. K. (1989). Thin layer solar drying of rough rice. Solar Energy, 42(2), 167-171. 
[19] Basunia, M. A., \& Abe, T. (2001). Thin-layer solar drying characteristics of rough rice under natural convection. Journal of Food Engineering, 47(4), 295-301.

[20] Midilli, A., \& Kucuk, H. (2003). Mathematical modeling of thin layer drying of pistachio by using solar energy. Energy Conversion and Management, 44(7), 1111-1122.

[21] Stegou-Sagia, A.; Fragkou, D. V. (2014). Influence of drying conditions and mathematical models on the thin layer drying of mushrooms. Proceedings of the ASME $201412^{\text {th }}$ Biennial Conference on Engineering Systems Design and Analysis, Copenhagen, Denmark.

[22] Rayaguru, K., \& Routray, W. (2012). Mathematical modeling of thin layer drying kinetics of stone apple slices. International Food Research Journal, 19(4), 1503-1510.

[23] Mirzaee, E., Rafiee, S., \& Keyhani, A. (2010). Evaluation and selection of thin-layer models for drying kinetics of apricot (cv. NASIRY). Agricultural Engineering International: CIGR Journal, 12(2), 111-116.

[24] Toğrul, I. T., \& Pehlivan, D. (2003). Modelling of drying kinetics of single apricot. Journal of Food Engineering, 58(1), 23-32.

[25] Kumar, M. Drying of Grapes (Thompson Seedless) using a Microwave-Vacuum Dryer., Thesis of M. Tech, Indian Institute of Technology Kharagpur, 2014.

[26] Doymaz, I., \& Akgün, N. A. (2009). Study of thin-layer drying of grape wastes. Chemical Engineering Communications, 196(7), 890-900.

[27] Xanthopoulos, G., Oikonomou, N., \& Lambrinos, G. (2007). Applicability of a single-layer drying model to predict the drying rate of whole figs. Journal of Food Engineering, 81(3), 553-559.

[28] Doymaz, I. (2010). Evaluation of mathematical models for prediction of thin-layer drying of banana slices. International Journal of Food Properties, 13(3), 486-497.

[29]Mariem, S. Ben, \& Mabrouk, S. Ben. (2014). Drying characteristics of tomato slices and mathematical modeling. International Journal of Energy Engineering 2014, 4(2A), 17-24.

[30] Purkayastha, M. D., Nath, A., Deka, B. C., \& Mahanta, C. L. (2013). Thin layer drying of tomato slices. Journal of food science and technology, 50(4), 642-653.

[31] Kouchakzadeh, A., \& Haghighi, K. (2011). Modeling of vacuum-infrared drying of pistachios. Agricultural Engineering International: CIGR Journal, 13(3).

[32] Taheri-Garavand, A., Rafiee, S., \& Keyhani, A. (2011). Study on effective moisture diffusivity, activation energy and mathematical modeling of thin layer drying kinetics of bell pepper. Australian Journal of Crop Science, $5(2), 128-131$.

[33] Mohanraj, M., \& Chandrasekar, P. (2008). Drying of copra in a forced convection solar drier. Biosystems Engineering, 99(4), 604-607.

[34] Mohanraj, M., \& Chandrasekar, P. (2009). Performance of a forced convection solar drier integrated with gravel as heat storage material for chili drying. Journal of Engineering Science and Technology, 4(3), 305-314

[35] Wang, Z., Sun, J., Liao, X., Chen, F., Zhao, G., Wu, J., \& Hu, X. (2007). Mathematical modeling on hot air drying of thin layer apple pomace. Food Research International, 40(1), 39-46.

[36] Panchariya, P. C., Popovic, D., \& Sharma, A. L. (2002). Thin-layer modelling of black tea drying process. Journal of Food Engineering, 52(4), 349-357.

[37] O'Callaghan, J. R., Menzies, D. J., \& Bailey, P. H. (1971). Digital simulation of agricultural drier performance. Journal of Agricultural Engineering Research, 16(3), 223-244.

[38] Moss, J. R., \& Otten, L. (1989). A Relationship Between Colour Development and Moisture Content During Roasting of Peanuts. Canadian Institute of Food Science and Technology Journal, 22(1), 34-39.

[39] Sharaf-Eldeen, Y. I., Blaisdell, J. L., \& Hamdy, M. Y. (1980). A model for ear corn drying. Transactions of the ASAE, 23(5), 1261-1265.

[40] Diamante, L. M., \& Munro, P. A. (1993). Mathematical modelling of the thin layer solar drying of sweet potato slices. Solar Energy, 51(4), 271-276.

[41] Wang, C. Y., \& Singh, R. P. (1978). A single layer drying equation for rough rice (No. 78-3001, p. 33). ASAE paper.

[42] Tulek, Y. (2011). Drying Kinetics of Oyster Mushroom ( Pleurotus ostreatus ) in a Convective Hot Air Dryer. Journal Agricultural Science Technology, 13, 655-664.

[43] Ertekin, C., \& Yaldiz, O. (2004). Drying of eggplant and selection of a suitable thin layer drying model. Journal of Food Engineering, 63(3), 349-359. 
[44] Sacilik, K., Keskin, R., \& Elicin, A. K. (2006). Mathematical modelling of solar tunnel drying of thin layer organic tomato. Journal of Food Engineering, 73(3), 231-238.

[45] Thompson, T. L., Peart, R. M., \& Foster, G. H. (1968). Mathematical simulation of corn drying-a new model. Transactions of the ASAE, 11(4), 582-0586.

[46] Verma, L. ., Bucklin, R. ., Endan, J. ., \& Wratten, F. . (1985). Effects of Drying Air Parameters on Rice Drying Models. Transactions of the ASAE, 28(1), 0296-0301.

[47] Aghbashlo, M., kianmehr, M. H., \& Samimi-Akhijahani, H. (2008). Influence of drying conditions on the effective moisture diffusivity, energy of activation and energy consumption during the thin-layer drying of berberis fruit (Berberidaceae). Energy Conversion and Management, 49(10), 2865-2871. 